\title{
ФИЛИП, КОЈ (НЕ) САКАШЕ ДА КРАЛУВА
}

\section{Кратка содржина}

За Филип од Амфакситида, братот на Пердика II, обично се вели дека спорел за правото на македонскиот престол. Но, овој наводен претендент не презел никаков воен потфат против Пердика сѐ до атинското вмешуваъе во 432 ст.е., ниту, пак, исковал монети или се обидел да устрои какво и да е спечифично тело со државна номенклатура. Ова навестува дека Филип ниту полагал право на престолот, ниту, пак, можел да смета на поддршка од македонското собрание или македонските првенци во Ајга. Анализата на случувањата укажува дека Филип едноставно одбрал да управува независно и престанал да иे полага сметки на престолнината. Тој прифатил борба за престолот дури откако ја загубил Амфакситида, но и откако обезбедил воена поддршка од Дерда од Елимеја и од Атина; пред тоа немал ниту сила, ниту доволно добар мотив за да се надбива за кралската власт. По дваесетина години опстојување во Амфакситида, Филип станал жртва на политичките интереси на Атињаните, кои од практични причини ја смениле страната, го погазиле договорот со него и со Дерда, и му дале поддршка на Пердика II.

Клучни зборови: ПЕРДИКА ІІ, ФИЛИП, АМФАКСИТИДА, АТИНА.

По смртта на Александар I Филхелен во 454 ст.е., ${ }^{1}$ неговиот син Пердика II се исправил пред тешка задача. Развојот на политичките и економските односи речиси од корен ја сменил сцената на дејствување. Пердика II се соочил со свет во кој непријателствата се раѓале и умирале во согласност со актуелниот политички миг или потреба, а во таков свет, ударот можел да биде упатен од секаде, па дури и однатре - од членовите на македонската кралска куќа.

1. Првото навестување дека примопредавањето на кралската власт не се одвивало како што било замислено го даваат податоците на старите хроничари. Списоците на македонските владетели и временските рамки на нивното владеење обично соодветствуваат со она што го дознаваме од наративните извори ${ }^{2}$ за жал, токму податоците за Пердика II покажуваат непомирливо неслагање. Хроничари-

\footnotetext{
${ }^{1}$ HAMMOND \& GRIFFITH (1979), 103, тврдат дека начинот и времето на смртта на Александар I cè уште не се расчистени. Поведувајќ́ се по податокот на Јустин (6.11.26, говорот на Филота), Хамонд цени дека Александар бил убиен, а дека тоа се случило во 452 ст.е.

${ }^{2}$ На пример, иако хронологијата на настаните од средината од V век ст.е. на многу места сѐ уште не е доволно расчистена, податокот дека Александар владеел четириесет и четири години (Sync. 469, 500; Diod. 7.15.2 apud Euseb.) убаво се вклопува во нашите претпоставки дека Александар владеел од 498 до 454 ст.е. Contra HAMмOND, v. претходната забелешка.
} 
те се поделени во две групи: едните велат дека Пердика владеел четириесет или четириесет и една година, а другите - во зависност од авторот - тврдат дека бил на престолот меѓу дваесет и две и дваесет и осум години. ${ }^{3}$

Првиот податок соодветствува со вообичаените пресметки. Смртта на Пердика може со задоволителна сигурност да се датира во 414/3 ст.е., ${ }^{4}$ па оттаму, ако владеел четириесетина години, Пердика го наследил престолот во 454/3 ст.е., веднаш по смртта на неговиот татко. Но, според вториот податок, излегува дека Пердика станал крал на Македонија само една деценија пред избивањето на Пелопонеската војна. Што се случувало дотогаш, и како да се сфати ова несогласување? Распонот од дваесет години е преголем за да се оправда со превид во пресметувањето. Единственото можно објаснување е дека, според античките автори, кралскиот авторитет на Пердика II извесно време бил оспорен.

И покрај скудните и патемни спомнувања во изворите, современите истражувачи се обиделе да ги постават основните определници на случувањата. Денес е општоприфатена претпоставката дека, непосредно пред да почине, Александар им поделил одредени одговорности барем на некои од неговите синови. Веројатно е дека Пердика сето време останал во Ајга, но Тукидид сведочи дека неговиот брат Филип имал некаква власт во Амфакситида; ${ }^{5}$ зборувајќи за подоцнежно време, Платон нафрла дека слични овластувања имал и третиот брат, Алкета, но не кажува каде. ${ }^{6}$ Се чини дека другите браќа не учествувале во власта: Синкел вели дека Аминта го минал целиот живот како обичен граѓанин, а последниот брат, Менелај, го знаеме само по име, и тоа од еден епиграфски споменик. ${ }^{7}$

За жал, тоа е сѐ што може да се извлече од изворите. Не знаеме зошто Александар се решил да преземе ваков чекор; не ни е кажано каде се протегала власта на Алкета, ниту, пак, ни е даден каков и да е податок за односите на Перди-

${ }^{3}$ На ова несогласување прв се осврнал Атенај (5.217e), кој забележал шест мислења: според Никомед од Акант, Пердика владеел 41 година, според Анаксимен - 40, Теопомп пресметува 35 години, Хиероним - 28, а Марсија и Филохор - 23. Кон ова би можел да се придодаде и Marmor Parium (FgrH 239 А 58) - 41 година, Синкел (469) - 23 и Диодор (7.15.2, кај Евсебиј) - 22. Очигледно, постоеле две спротивставени струи - историографите од времето на Филип II ценеле дека Пердика владеел подолго, а оние од времето на Александар III поскоро се решавале да му припишат покусо владеење. Оваа схема е забележана кај HAMMOND \& GRIFFITH (1979), 104, во дискусијата за смртта на Александар I.

${ }^{4}$ Според следот на настаните кај Диодор (14.37.6), Архелај умрел во 399 ст.е., а Синкел (494 и 500) на Архелај му припишува владеење од четиринаесет години. Кај Тукидид (7.9), Пердика во летото 414 ст.е. војува кај Амфипол, а веќе во 411/10 Архелај ја опсадува Пидна.

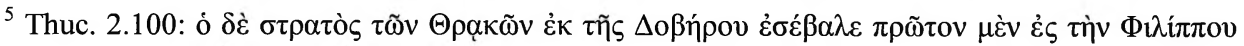

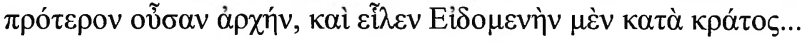

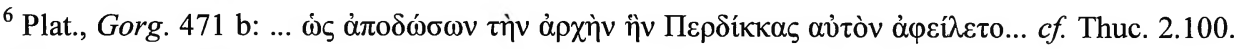
3; Plato, Res publica 336a; BorZA (1992), 133 sqq.

7 За Аминта, v. Sync. 500 (Dindorf); за Менелај, IG I ${ }^{3}$ 89. Kaj HAMmOND \& GRIFfith (1979), 115 , се споменува можноста дека обајцата браќа се спомнати и кај Ајлијан (7.2.41); Droysen $\left(1.1^{2} .67\right)$ и Abel (167) спекулираат дури и за нивната возраст, како и за териториите што им припаѓале. 
ка со неговите браќа. Уште поважно, денешните истражувачи тврдат дека Пердика и Филип спореле за македонскиот престол - но, вистината е дека никаде во изворите не се кажува што било спорно и каде избиле недоразбирањата. Некои делови од оваа сложувалка можеби и можат да се пополнат но, за да го сториме тоа, ќе тргнеме во насока спротивна од очекуваната: токму разгледувањето за причините на спорот меѓу браќата ќе нѐ однесат наназад, до суштината на несекојдневниот потег на Александар и до вистинскиот карактер на спорот Пердика II и Филип од Амфакситида.

2. Да тргнеме од положбата на Филип, кој, како што се верува, спорел за правото на престолот. Тој би можел да влезе во таков спор само ако имал основа да ги поткрепи своите тврдења, што би значело или дека Пердика не бил препорачан од својот татко (значи, дека Александар препорачал друг наследник пред македонското Собрание), дека не бил најстариот син (значи, дека не било почитувано правилото за примогенитура), или, пак, дека не бил законски определениот наследник (значи, дека завладеал спротивно на волјата на Македонците). Како што видовме, изворите не ни кажуваат ништо ниту за тоа кој бил најстар, ниту, пак, за начинот на кој било извршено примопредавањето на власта; затоа, ќе мора да прибегнеме кон посредно изведување на собитијата.

Ако природното право на престолот му следувало на некој друг, а не на Пердика, тоа тешко можело да остане незабележано во атинските извори од тоа време: Атина била доволно заинтересирана за состојбата на северното крајбрежје за будно да ги следи случувањата во кралската куќа. ${ }^{8}$ Атињаните можеби го обвинувале Пердика дека е лажго и измамник, но никогаш не му префрлиле дека е узурпатор. Понатаму, при сѐ што процесот на наследувањето на македонскиот престол сѐ уште не е доволно расветлен, едно нешто е повеќе од јасно: кралот немал право да назначи свој наследник. ${ }^{9}$ Тој единствено можел да ја искаже својата наклоност, а за наследникот - според правилото за примогенитура, со оглед на телесната и духовна способност, или пак во согласност со политичката состојба решавало македонското Собрание. ${ }^{10}$ Значи, ако во 454 ст.е. Пердика бил крунисан

${ }^{8}$ Како што, впрочем, и Демостен не би пропуштил да спомне дека Филип II не бил легитимен крал, ако овој навистина му го одзел престолот на малолетниот Аминта, v. ПроЕВА (1997), 50. Во најмала рака би очекувале Пердика да биде наречен vóӨo барем кај Хермип

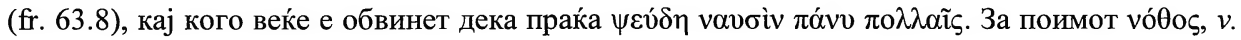
HATZOPOULos (1986), 292, како и опсежната анализа на поимот кај CARLIER (1992).

${ }^{9}$ Опшиирно за ова кај ПРОЕВА (1997), 49-79. $C f$. задолжително и прегледниот приказ на BORZA (1999), 44 sqq., како и GRANIER (1931), 18-19, 25-31; HAMMOND \& GRIFFITH (1979), 161162. Contra ANSON (1985), 305, но неговите примери се, без исклучок, од подоцнежно време и се однесуваат на македонското кралство по Александар - државна организација која никако не може да послужи како показ за состојбата во времето на Пердика II. Историјата на изучувањата на уредувањето на македонското кралство е опфатена кај Borza (1992), глава 10, како и кај HAMMOND (1989), глави 2, 4, 7 и 8.

${ }^{10} C f$. задолжително Hatzopoulos (1996), 276 sqq. Contra Anson (1985), 308, кој цени дека прогласувањето на кралот се случувало пред присутните граѓани/војници кои се затекнале на местото на настанот ("If the king had died in Pella, the population of Pella might have been 
во Ајга, тоа морало да се случи со општа согласност на Македониите, што не би можело да се случи ако правото на престолот му припаѓало на некој од другите браќа. ${ }^{11}$

Уште еден аргумент произлегува од постапките на наводниот претендент. Во изворите не е забележан никаков воен потфат на Филип сѐ до атинското вмешување во 432 ст.е. Од она што досега го знаеме, ниту еден од браќата на Пердика - дури ни Филип, кој од Амфакситида имал полесен пристап до наоѓалиштата на сребро, одошто Пердика од Ајга - не исковал монети. ${ }^{12}$ Исто така, никаде не се споменува двојност во институциите, ниту, пак, обид да се устрои какво и да е специфично тело со државна номенклатура во Амфакситида.

Се чини дека божемниот претендент на престолот не бил многу претприемчив во обидите да го добие она на што полагал право. Тој не повел војска кон македонската престолнина; не се обидел да го објави и да го заговара своето право со сопствени монети; не се нарекувал крал на Македонците; и, најпосле, не се обидел од своето седиште да направи паралелна престолнина. Вакво однесување не може да се очекува од човек кој спори за престолот. Всушност, ако се набљудува состојбата до атинското вмешување, непреземањето на каков и да е потфат против Ајга поскоро говори дека Филип ниту полагал право на престолот, ниту, пак, можел да смета на поддрика од македонското Собрание или македонските првенци во Ајга. Во што, тогаш, се состоел спорот, и што сакал Филип да постигне?

3. Според сѐ, главниот виновник за тоа што Филип воопшто можел да му се спротивстави на Пердика бил токму Александар I, кој ги создал сите предуслови за ова преку неговата поделба на одговорности и овластувања во кралството. ${ }^{13}$ За причините можеме само да спекулираме, но здравата логика укажува дека Алек-

called on for the ceremonial acclamation; if in Aegae, the population of Aegae. Some populations would be more prestigious than others, especially if there were multiple claimants, but, in general, any group would probably do."). Но, примерот што го дава како поткрепа на ова тврдење ("It was to enhance his standing as a claimant to Philip II's throne that Argaeus unsuccessfully invited the population of Aegae to acknowledge him as king") го сведочи токму спротивното - во случајов, нагласката е на конструкцијата "to enhance his standing", а не за да биде прогласен за крал.

${ }^{11}$ Примогенитурата можеби важела само за децата кои биле родени кога таткото веќе бил крал; родените пред тоа не можеле да учествуваат во власта. За ова, како и за некои други нијанси, v. HATZOPOULOS (1986), 291. Како и да е, едноставната математика покажува дека, ако Пердика бил роден пред 498 ст.е., во 414/3 би имал најмалку 85 години; не е многу веројатно дека на таа возраст би можел да води војска и, заедно со атинскиот војсководец Еветион, да се бори кај Амфипол, а според Тукидид - го правел токму тоа.

${ }^{12}$ Како што, на пример, подоцна направиле Аминта „Малиот“ и Павсанија со монетите од 394/3 ст.е. Но, оваа паралела не важи ако Аминта и Павсанија биле совладетели, а не соперници; прашањето не е расчистено. $C f$. прегледот на DAHMEN (2010), 50 sqq.

${ }^{13}$ Pace COLE (1974), кој, сепак, до овој заклучок доаѓа по поинаков пат. Тој, имено, цени дека стратегиската важност на долината на Аксиј е доволен доказ дека Филип ги добил овластувањата од Александар I. Пердика, вели авторот, никако не би дозволил, уште помалку би му дал на Филип да управува со толку значајна област. 
сандар очекувал позитивен ефект. Јасно е дека поделбата не била ниту воспитна, ниту образовна мерка; ${ }^{14}$ од неа не требало да извлечат полза синовите, туку кралството. Значи, треба да се претпостави дека со оваа поделба требало да се стави крај на некој негативен тренд, т.е. да се поправи нешто што не функционирало доволно добро.

Во времето што нѐ интересира - откако минала персиската бура, а Атина накусо се свртела кон Пелопонез, Египет и Персија - единствено што не функционирало доволно добро било наметнувањето на централната администрација во новостекнатите области. Некаде пред 465 ст.е., без судир и со обострана согласност, Александар се повлекол од Едонија и ѝ ја оставил на управување на месната владетелска куќа. Решението било целесообразно, но трендот, сепак, бил негативен и никако не смеел да се вкорени. Ограничените можности за контрола, во сплет со формалното „ослободување“ на Едонија, лесно можеле да го прелеат овој тренд кон запад и да предизвикаат неприлики со Бисалтите, Крестонците и Мигдонците. Со ова би се создале услови границата повторно да се врати речиси до Аксиј, па военото дејствување станувало неминовно.

Да се прифати ваква состојба на нештата би било апсурдно, зашто овие области ниту биле непосредно загрозени однадвор, ниту, пак, требало да се обезбедат и да се бранат од која и да е друга страна, освен од јужната. Многу пологичен потег бил да се засили увидот на престолнината во случувањата на теренот, со што би се решиле проблемите предизвикани од недоволно ефективната администрација и отежнатите комуникации со Ајга. Областите требало да се управуваат непосредно, а нивната инфраструктура да се насочи кон потребите - значи, да се стави во функција - на државата. Ова требало да се направи релативно брзо и исполнително, зашто Атина, иако во моментот зафатена на друго место, сепак, била сѐ поприсутна во непосредното соседство. Сѐ упатува на тоа дека, по повлекувањето од Едонија, Александар морал во најкус можен рок да ја уреди непосредната управа во новите области, по можност - под водство на човек во кого имал апсолутна доверба. Навистина е тешко да се посочи кого кралот поскоро би го одбрал за оваа задача ако не еден од своите синови.

Оттаму, најверојатниот след на приказната е дека синовите на Александар добиле овластувања за непосреден надзор и управување на областите источно од Аксиј. Нивната улога била цивилна и управна, а не воена и одбранбена. ${ }^{15}$ Тие имале задача да внимаваат потребите и интересите на кралството да бидат запазувани без одлагање и притисок, да ги јакнат внатрешните врски со Ајга, а со своето непосредно присуство едновремено да влијаат и врз случувањата во соседството.

\footnotetext{
${ }^{14}$ HODLOFSKI (1979), 92, дозволува и ситуација во која Александар не бил сигурен кому да му го остави кралството, та затоа сакал да поттикне надбивање преку докажување на личните способности. Непотребно е да се истакнува дека Александар имал поважни работи одошто да експериментира со сопственото кралство во психолошки и педагошки цели.

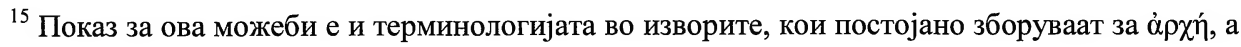

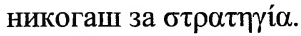


Иако непосредната управа се спроведувала на локално ниво, за примената на приходите од земјата, како и за воените прашања решавал кралот.

Токму тука ја откриваме слабата точка на поделбата на Александар. Ако таа навистина била замислена вака, нејзиниот успех бил непосредно условен од моќта на централната власт. ${ }^{16}$ Ваков систем на управување може да функционира само во услови на непречена двонасочна комуникација меѓу престолнината и нејзините луѓе на теренот. Ако централната власт нема постојан увид во работата на управниците што ги назначила, се јавуваат и првите неприлики: назначените управители можат да одбијат да ги следат определниците од престолнината. Нивните овластувања не вклучуваат контрола на војската, туку се цивилни, врзани за земјата и приходите од неа: преземањето целосна контрола значи дека престолнината е директно оштетена, зашто е лишена од економските благодати, кои сега остануваат во посед на управителот. Тој, пак, акумулира недозволиво голема економска моќ и цивилно влијание, а неговото седиште добива тежина на регионален центар, намалувајќ ја на тој начин потребата од односи со престолнината.

Мошне е веројатно дека нештата се одвивале во оваа насока. Би било наивно да се помисли дека авторитетот на Пердика кај неговите браќа имал иста тежина како авторитетот на Александар I. Без оглед дали тоа било побарано од него, ${ }^{17}$ Филип не само што решил да не ги предаде овластувањата, ${ }^{18}$ туку, едноставно, ги прекинал врските со престолнината и управувал со Амфакситида, но за своја сметка. Немаме доволно податоци за да судиме за политичката дарба на управителот на Амфакситида, но се чини дека, можеби и без таква намисла, неговиот потег предизвикал цврста пат-позиција. На едната страна стоел Филип, кој не го оспорувал правото на Пердика да биде крал, ниту, пак, можел или сакал да го нападне со војска, туку едноставно одбрал да управува независно и престанал да иे полага сметки на престолнината; на другата страна бил Пердика, кралот на Македонија, кој несомнено сакал да го нападне и отстрани својот брат, но притоа не можел да смета на поддриката на месното население: состојбата на теренот укажувала дека борбата ќе биде осудена на неуспех. ${ }^{19}$ Поставен на средина на кралството, Филип ги попречувал комуникациите на престолнината со источните области, со што Пердика го загубил не само увидот во случувањата на исток, туку

\footnotetext{
${ }^{16}$ Правилно забележано од BoRZA (1990), 135. RoISMAN (2010), 146 е поостар и го оценува потегот како “а recipe for trouble". Но, современиот истражувач не може да се оддели од свеста за тоа како завршила целата работа; hindsight is the perfect general.

${ }^{17}$ Како што мисли COLE (1974), 55-57.

18 За разлика, на пример, од Алкета, кој најверојатно се откажал од своите овластувања во корист на Пердика по мирен пат. Всушност, не можеме со сигурност да кажеме дали тоа се случило по комбинација од воен притисок и политичко убедување, или пак сосем доброволно, но преземањето на овластувањата минало без фактички судир; за ова сведочи $I G \mathrm{I}^{3}$ 89 , каде што името на Алкета стои веднаш по Пердика. Дискусија за датирањето на натписот кај Errington (1990), 267; cf. HAMMOND \& GRIFFITH (1979), 132 sqq.

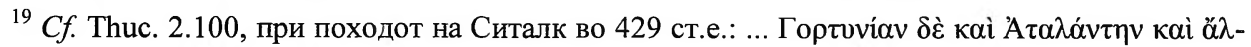

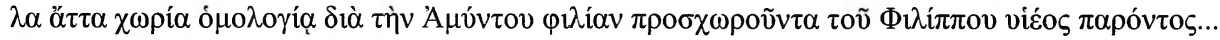


и пристапот до наоѓалиштата на сребро; ${ }^{20}$ од друга страна, реалната моќ на неговиот соперник не била доволна за тој да ја прошири контролата кон исток. Накусо кажано, Пердика бил законски избраниот крал на Македонците; Филип тоа не го оспорувал, но одбил да биде негов поданик. Тој имал намера да продолжи да управува со Амфакситида, а Пердика, колку и да сакал, извесно време не можел да стори ништо за да го спречи.

Искрите меѓу Пердика и Филип најмногу се одразиле токму онаму каде што и претходно проблемите биле најсериозни - на полето на управата. На пример, замирањето на државната администрација во Бисалтија, како и неможноста проблемот да се санира макар со засилено воено присуство, речиси го збришала влијанието на Аргеадите во оваа област. ${ }^{21}$ Кога Александар I слегол од историската сцена - а со него и неговиот углед и искуство - Бисалтите, без мотив да се врзат ниту за Пердика ниту за Филип, останале препуштени сами на себе. ${ }^{22}$ Приликите секако биле матни и, гледано од поширок агол, не оделе во прилог на ниту една страна.

4. До кога траело ова разногласие во Македонија? Не можеме да кажеме со сигурност, но се чини дека нешто може да се насети токму од текстот на Тукидид. ${ }^{23}$ Уште пред да избие бунтот во Потидаја, Атињаните пратиле на север дел од својата флота со илјада хоплити. Тие, пак, требало да дејствуваат во соработка со локалните сили на Филип и Дерда, кои веќе започнале некакви дејства против

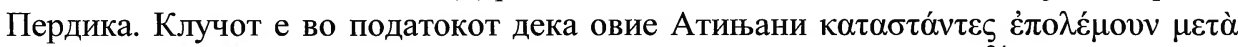

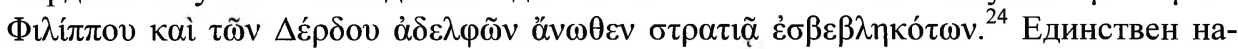
чин да се објасни зборот о̆ $\omega \omega \theta \varepsilon v$ е да се претпостави дека овие сили дошле од Гор-

${ }^{20}$ Пердика II ковал само лесни и тешки тетроболи. За можните проблеми во врска со класификацијата на неговите монети, v. DAHMEN (2010), 51, n. 41; PRICE (1974), 20; WestermarK (1989), 303.

${ }^{21}$ Некои истражувачи (на пример, HAMMOND \& GRIFFITH (1979), 119) веруваат дека слабеењето на Пердика има одраз и во монетоковањето; имено, македонскиот крал не исковал монета поголема од тетробол, што се објаснува со претпоставката дека за извесно време го загубил пристапот до бисалтското сребро. Пристапот на BORZA (1990), 133, е попретпазлив: тој потсетува дека потпирањето исклучиво на нумизматички извори може да залаже, зашто наодите најчесто се статистички погрешни. Слабеењето на Пердика и осамостојувањето на Бисалтите има потпора во општиот тек на случувањата; сепак, се чини дека немањето сребрени монети од времето на Пердика може да се објасни и поинаку. На пример, целото достапно сребро не било секогаш ковано во монети; ако рудниците навистина му носеле на Александар по еден талант дневно, слободно може да се претпостави дека Пердика располагал со залихи од нековано сребро. Но, зошто решил да не кова монети, може само да се претпоставува. На пример, ПРОЕВА (1997) цени дека Пердика ковал тетроболи зашто сакал да ја потикне монетарната економија на внатрешен план, откако Александар тоа веќе го сторил со надворешните пазари (Историја на Аргеадите, во подготовка).

${ }^{22}$ Слично кај HodlofSKI (1979), 93.

${ }^{23}$ Се чини дека BADIAN (1993), 173 sqq. прв ја забележал важноста на деталите за кои ќе стане збор во продолжение.

${ }^{24}$ Thuc. 1.59 . 
на Македонија, значи - од Елимеја. Ако Филип сѐ уште ја држел Амфакситида, единствен логичен начин да се војува би бил - а) Дерда да нападне по долината на Халиакмон, од Елимеја кон Пиерија; б) Филип да се спушти од Амфакситида во Ботиаја, и в) Атињаните да удрат на брегот, во висина на Метона и Пидна, или, пак, да се вклучат онаму каде што ќе бидат најпотребни. На тој начин, Пердика би бил принуден да се брани на најмалку два копнени фронта, не сметајќ ги неприликите кои би му ги предизвикала флотата. Но, нештата не се одвивале така: Филип и Дерда стоеле на чело на една иста воена сила, која се пробивала од Горна Македонија. Бидејќи не може да се објасни како Филип би минал со војска преку Ботиаја за да му се придружи на Дерда, ниту, пак, може да се најде мотив за таквиот маневар, станува јасно дека Филип не дошол од никаде, туку во тоа време веќ бил во Елимеја. Сосем е веројатно дека, откако на еден или друг начин ја загубил Амфакситида, Филип нашол засолниште кај Дерда.

Ова се согласува со претпоставката што беше изложена погоре: Филип прифатил борба за престолот дури откако ја загубил Амфакситида, но и откако обезбедил воена поддрика не само од Дерда, туку и од Атина. Пред тоа немал ниту сила ниту доволно добар мотив за да се надбива за кралската власт.

5. Сепак, позицијата на Атина била поинаква одошто би можело да се очекува на прв поглед. Слабоста на македонското кралство несомнено ѝ одела во прилог на Атина, а неможноста на Пердика (или на Филип) да се зацврсти на териториите меѓу Ехедор и Стримон ја олеснувала нејзината потрага по сојузници и населби на северното крајбрежје. Па сепак, оваа состојба имала темна опачина. Приликата да се искористи слабоста на Македонија, и непречено да се навлезе во периферијата на нејзината интересна сфера, била секако добредојдена - но, сосем друго нешто било оваа слабост да стане постојана. Атина имала важни интереси на крајбрежјето и во Стримонскиот басен, но уште поважни интереси ја врзувале за македонското кралство. Главните испораки на дрво, врз кои се темелела атинската превласт на море, сѐ уште доаѓале од Пиерија и биле овозможени преку соработката со македонскиот крал. До основањето на населба со која би се обезбедил пристап до едонското дрво, неприликите на Пердика можеле да станат и неприлики на Атина. И повеќе од тоа, долгорочно безредие на северот можело да биде опасно за атинските интереси, но и за безбедноста на потфатите кај Стримон. Кавгата меѓу Пердика и Филип ја ставила Атина меѓу два огна: во нејзин интерес било состојбата да се смири, но истовремено и да не се стабилизира во потполност.

Немаме јасни сведоштва каков бил македонскиот одговор на атинските успеси, ниту, пак, можеме со сигурност да кажеме какви биле односите меѓу Пердика и Атина на почетокот од неговото кралување. Иако бројот на членови на Атинскиот поморски сојуз на брегот на Халкидик бил сразмерно голем, а атинското присуство во Ботика, во Крусида и на Палена мошне забележително, во даночните списоци нема податок за нови полиси од Термајскиот Залив или, воопшто, од 
непосредното соседство на Пердика. ${ }^{25}$ Според сѐ што ни е на располагање, би можеле да заклучиме дека, и покрај атинските активности, односите меѓу Атина и македонското кралство не биле сериозно нарушени. Пердика немал влијание на териториите каде што навлегла Атина, па дури и да не му се допаѓало тоа, не можел ништо да стори. Од друга страна, Атина мудро избегнувала да поведе каква и да е нова иницијатива на териториите што сѐ уште биле во интересната сфера на Пердика, па кралот немал вистински повод за да започне непријателство. ${ }^{26}$

Сепак, јасно е дека текот на случувањата предизвикал непријатност во Аjга. Ако сакала да изнуди признавање на тековната состојба, Атина требала, за возврат, да положи некаков залог.

6. За да ги избегне неуспесите од времето на Кимон, Атина се однесувала претпазливо: таа внесувала мал број населеници на северното крајбрежје, постојано одржувајќи позитивна расположба кај своите нови соседи. Па сепак, основањето на Амфипол во 437/6 ст.е. - чин со кој се навестувало заокружувањето на целите на атинската политика на северот - никако не би можело да се означи како постапно, прикриено или претпазливо. Големината на населбата, улогата што ѝ била наменета, учеството на хеленски населеници од други полиси, присуството на воена сила и, воопшто, маркантноста на целиот потфат укажуваат дека чинот на основање бил претходно обезбеден и договорен. Потфат со толкави размери и влијание тешко би можел да се спроведе, ако некој во регионот посакал да го спречи или оспори. Затоа, сосем е веројатно дека, пред да пристапи кон основањето на Амфипол, Атина успеала да се спогоди со сите заинтересирани политички сили во регионот. Териториите источно од Стримон биле смирени преку спогодбата со тракискиот басилеј Ситалк, но на запад сѐ уште тлеел раздорот во македонската кралска куќа. Логично продолжување на атинската агенда било склучување на некаква спогодба и со Македонците; ${ }^{27}$ за жал, неа кај Тукидид ја нема. Многумина сѐ уште спорат дали Тукидид воопшто навестува спогодба или сојуз на Атина со Пердика, па сепак, се чини дека таквиот скептицизам е пренагласен. Терминоло-

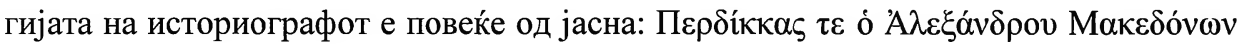

25 Западно од Стримон се наоѓале, меѓу другите, Ајнеа, Дикаја, Смила, Гигон, Хајса, Китада, Потидаја, Акант и др., членови на сојузот веројатно уште од почетокот. Споменувањето на Стрепса е проблематично: нејзината местоположба во делтата на Ехедор и Аксиј е претпоставена благодарение на еден податок кај Тукидид кој, како што ќ видиме, можеби е емендиран на погрешен начин.

${ }^{26} C f$. сумарниот преглед на атинските активности кај RoISMAN (2010), 146-147.

${ }^{27}$ Исто и кај COLE (1974), 60, кој цени дека при основањето на Амфипол морало да се води сметка и за Македонците: Пердика не можел да се вмеша, но атинската политичка линија несомнено наложувала и тој да биде вклучен во настаните. COLE, исто така, цени дека уште од ова време Атина се трудела да ги противпостави Ситалк и Пердика во сопствена полза; сепак, се чини дека состојбата сѐ уште не била доволно расчистена за да се прават такви пресметувања. HOFFMAN (1975), 366, тврди дека односите меѓу Атина и кралството биле толку лоши што Пердика реагирал со гнев на основањето на Амфипол; не е сосем јасно врз што се темели ваквата претпоставка, особено зашто авторот тврди дека Пердика и Атина склучиле сојуз уште во 454 ст.е. 


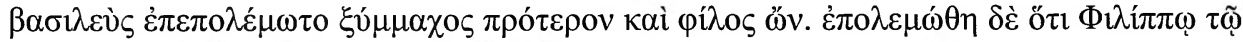

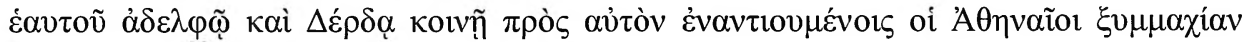

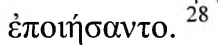

Податокот дека Пердика претходно бил фí $\lambda$ os е разбирлив и очекуван.

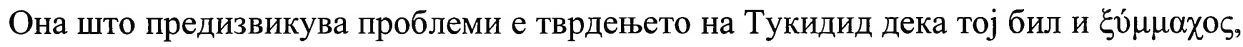
(воен) сојузник. Поимот јасно посочува сојузништво во борба, што, пак, подразбира склучување - ако не на сојуз - барем на некаква формална спогодба. ${ }^{29}$ Но, Пердика и Атињаните дотогаш не се бореле рамо до рамо во ниту една војна; дури, би можело да се каже дека, за сето време откако Пердика станал крал, нивните потфати одвај имале допирни точки. Ако ја отфрлиме можноста дека Тукидид невнимателно употребил термин без реална подлога - што е крајно неверојатно - ни преостанува само да заклучиме дека историографот нѐ запознал само со крајниот исход од некој настан, за кој инаку нема ниту збор во неговото дело.

За што би можело да станува збор? Да си приспомнеме дека Тукидид никаде не соопштува за судбината на Амфакситида и начинот на кој Филип ја изгу-

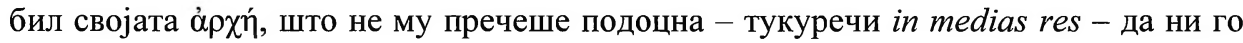
прикаже како, заедно со Дерда, слегува против Пердика од Горна Македонија. Оттука, се чини, почнува расплетот на нашите неприлики со текстот. Во првата наративна епизода Филип е во Амфакситида, потоа нешто е испуштено, за наеднаш

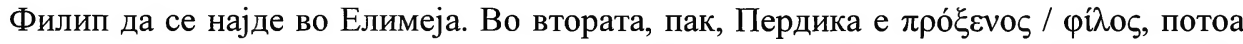

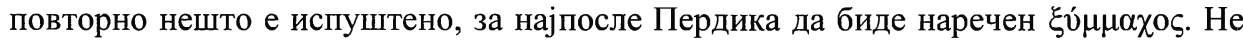
треба посебно да се потцртува колкава е веројатноста обете лакуни да се однесуваат на еден ист настан - оној што кај Тукидид го нема, а во кој Филип ја губи Амфакситида. Да разгледаме како тоа би можело да се случи.

7. Ако се земе предвид целата заднина на случувањата, она што Тукидид ни го соопштува е недоволно и скудно. Овие дваесетина збора не можат да се сфатат поинаку одошто како груба схема на настаните, во која недостасува цела низа важни детали и, над сѐ, објаснување. Ова, пак, нѐ обврзува да се задржиме на овој пасус поподробно и со поголемо внимание.

Прва интересна забелешка: Тукидид само навидум признава дека за почетокот на непријателствата е виновна Атина. Ако наводот се следи дијахроно, Пердика навистина станал непријател дури откако Атина се сојузила со неговите соперници; но, тука се важни јазичните нијанси. Во мигот кога Атина склучила со-

28 Thuc. 1.57.3.

${ }^{29}$ Податокот на Теопомп (зачуван кај Страбон, 10.1.3), кој единствен споменува контакт и спогодба меѓу Македонија и Атина пред 432 ст.е., се однесува на судбината на прогонетите Хестиајци. Крајот на непријателствата на Евбоја, ако се следат наводите на Тукидид (1.114.3), Диодор $(12.7,12.22 .2)$ и Плутарх (Pericl. 23), може да се датира во 446 ст.е., што е премногу рано за да ја покрие и спогодбата во врска со Амфипол. Според издавачите на $A T L$, во 437/6 може да се датира веќ безброј пати толкуваниот $I G \mathrm{I}^{3} 89$ - за што поопширно ќе проговориме подоцна - но се чини дека овој натпис, сепак, е подоцнежен. Според сѐ, изгледа дека спогодбата која (можеби) била склучена во 437 воопшто не е забележана во изворите - што не мора да значи дека не се случила. 


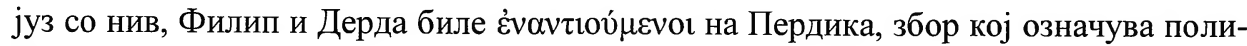
тичка или дипломатска противпоставеност, несогласување во ставовите и делата но не и соперништво во војна. ${ }^{30}$ De iure, Филип и Дерда сѐ уште не биле непријатели на Пердика, та атинскиот сојуз со нив не бил акт со кој се прекршувала спогодбата од 437. Потегот на Атина можел да биде протолкуван како чин на преду-

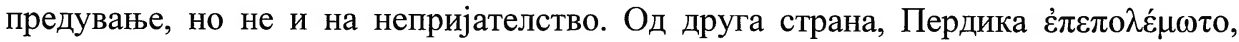
што може да значи само војна. Тукидид, значи, ни кажува дека спогодбата ја прекршил Пердика. ${ }^{31}$

Би било убаво ваквото тврдење да се поткрепи со доказ, но докази кај Тукидид нема. Во она што тој ни го раскажува - а бездруго го раскажува само она што мисли дека е потребно - Пердика не презема ниту една формална воена акција на непријателство. Дали Пердика воопшто можел да биде виновен за раскинувањето на спогодбата? ${ }^{32}$ Кон прашањето мора да се пристапи од повеќе страни: треба да се разгледа не само воената подготвеност на Пердика, туку и миговните политички и економски условености на Македонија и Атина.

Речиси е сигурно дека Пердика во 432 не бил доволно силен за да ги загрози атинските поседи ниту на Халкидик, ниту во Стримонскиот басен. За да се справи со Филип, на Пердика му била потребна помош однадвор, зашто Крестонија и Бисалтија биле надвор од опсегот за успешни воени дејства. Секој непријателски потег на Пердика би предизвикал жесток и уште посилен одговор: дејствата против Атина биле потфат со висок ризик, нешто што на Пердика воопшто не му требало.

Не треба да се заборави и тоа дека суштината на спогодбата од 437 не била да му се даде помош на Пердика, туку да се обезбеди атинското присуство на

${ }^{30}$ Pace BADIAN (1993), 172. Датумот на сојузот со Филип и Дерда не може да се утврди со сигурност. Тукидид, кој очигледно не дава целосен преглед на настаните, само кажува дека атинските барања во врска со Потидаја уследиле веднаш по битката кај Сиботските Острови, зашто и Коринтјаните и Пердика веќе станале атински непријатели (1.57.3). Битката се случила во септември 433. KAGAN (1994), 277 sqq. цени дека непријателството се развило набргу по основањето на Амфипол и дека договорот со Филип и Дерда можел да се случи уште во 435.

${ }^{31}$ Мошне е важна уште една, благо нагласена нијанса: Пердика несомнено бил неверен и недоверлив сојузник, инаку Атина не би имала потреба да склучи сојуз со неговите соперници. Тукидид, навистина, не е атински апологет: тој ги слика атинските доблести, но и недостатоци, па сепак, мошне е силен впечатокот дека неговите забелешки по правило се однесуваат на настаните на атинската политичка сцена. Што се однесува до надворешните односи, Атињаните според Тукидид никогаш не прекршиле договор, ниту, пак, изневериле сојузник.

32 COLE (1974), 61, цени дека Атина дејствувала премногу отворено во обидите да воспостави контрола над Термајскиот Залив, што предизвикало соодветна реакција од Пердика. Претпоставката на авторот се темели врз датирањето на приемот на Метона во сојузот во 434 , но датирањето сѐ уште е спорно. Метона се јавува на форосните списоци од 432/1, но издавачите на $A T L$ го реконструираат името и на списоците од 434 со цел да се усогласи една друга хронологија, онаа на Метонските декрети ( $A T L 3.133-137$; за декретот, $I G \mathrm{I}^{2}$ 57). Cf. HAMMOND \& GRIFFITH (1979), 124-129. 
Стримон: со прифаќањето на оваа спогодба, Пердика се согласил да не навлегува во атинската интересна сфера. Од стојалиштето на Пердика, било логично таквото навлегување и свесно да се одбегнува: и покрај сѐ, Атина сѐ уште била извонреден долгорочен трговски партнер со кој се остварувала размена во забележителен обем. Заладувањето на односите и прекинот на трговијата би биле несомнено штетни за Атина, но, од друга страна, Пердика би останал без главната придобивка од трговијата со дрвна граѓa - не атинското сребро, туку можноста дрвото да се користи како политички адут.

Како што ние ги премеруваме сите можни насоки на дејствување, тоа, секако, пред нас го сторил и Пердика. И, ако дури и по сево ова, сепак, решил да го прекрши мирот со Атина, тогаш неговиот пристап кон нештата бил оптимистичен и, би рекле, прилично агресивен. Зад агресивната политика мора да стои воена моќ, па со право би се запрашале - врз која стратегија и на чија помош Пердика сметал да се потпре за да ги оствари своите цели? Јасно е дека Пердика не размислувал за војна, ниту, пак, се залажувал дека може лесно да ги отстрани Атињаните од непосредното соседство. Непријателствата од 432 не биле предизвикани од некаков антиатински потег на Пердика, туку биле исход на атинските стратегиски цели на северното крајбрежје. ${ }^{33}$ Подготвувајќ се за војна, Атина го зголемила форосот $^{34}$ и се поврзала со најсилните соперници на македонскиот крал. Требало уште да се прати соодветна хоплитска сила и да се порази Пердика во пресуден бој.

Во април 432, од Пиреј најпосле испловила „македонската експедиција“. Воената сила, составена од триесет триери и илјада хоплити, ја предводел Архестрат Ликомедов. ${ }^{35}$ Задачите што ги добил биле куси и јасни: атинските сили требало да дејствуваат во спрега со борците на Филип и Дерда, сѐ дури не му биде зададен конечен удар на македонскиот крал. Станувало збор за задача за чии подготовки веќе биле потрошени средства, време и политички напори, та затоа и не се очекувало да се развлече до бесконечност. Така, штом веќе се упатил кон север, Архестрат можел да испита и дали Потидајците започнале да ги исполнуваат барањата на хегемонот и, во најлош случај, да земе заложници.

Архестрат се истоварил на брегот на Термајскиот Залив, токму на половина пат меѓу Пердика и Потидајците. Во тоа време, Филип и Дерда веќе ја извеле

${ }^{33}$ Contra BADIAN (1993), кој цени дека нема доволно податоци за да се размислува зошто Атина би се свртела против својот сојузник, и спекулира дека Атина се плашела дека моќта на Пердика можела да стане преголема. Но, јасно е дека иницијативата најмалку била во рацете на македонскиот крал. Впрочем, ако Пердика навистина бил доволно силен за да започне непријателства, несфатливо е зошто не реагирале воените посади во Бреа, Амфипол и Ејон. Против него била пратена војска од Атина, која испловила дури во април 432.

${ }^{34}$ Атинските сојузници секако не биле воодушевени од развојот на настаните. Сепак, нивните раце биле врзани, зашто крајбрежните населби биле на дострел на атинската флота, не биле далеку ниту стримонските воени посади, а не можеле да се надеваат на помош од Пердика, кој, впрочем, сосем веројатно бил следната атинска цел.

${ }^{35}$ Thuc. 1.57.6. KagAN (1994), 280 цени дека станува збор за истиот Архестрат кој, заедно со Ефијалт и Перикле, се борел да ја ограничи моќта на Ареопагот. 
војската од Елимеја и, најверојатно, дејствувале по должината на текот на Халиакмон, движејќ се кон Пиерија и Ботиаја. Силите на Пердика биле потребни во внатрешноста, па Атињаните лесно ја освоиле Терма. Но, каде да се продолжи? На Архестрат не му требало многу да разбере дека она што се случува во Потидаја е вистинско востание, и дека со силите што му биле дадени нема можност да стори ништо. Сосем исправно, откако Потидаја излегла од игра, тој решил да го префрли дејството поблизу до своите сојузници. Филип и Дерда бездруго се пробивале кон крајбрежјето и, штом работите стоеле така, Архестрат решил да им се посвети на првичните заповеди и да продолжи со дејствата против Пердика. ${ }^{36} \mathrm{Ha}$ почетокот на мај 432, Архестрат ја опсадил Пидна.

Вестите за случувањата во Потидаја бргу стасале во Атина. Станувало очигледно дека, дури и без поттик однадвор, атинскиот систем на контрола на Халкидик бил пред распаѓaње, и тоа токму во мигот кога во соседството се водела клучна војна. Атињаните морале по вторпат да праќаат војска: во Македонија стасал Калија Калијадов со четириесет триери и две илјади хоплити. ${ }^{37}$

Тукидид не ни ги соопштува заповедите што ги добил Калија, но споменува дека војсководецот ѝ се приклучил на опсадата, зашто се надевал дека градот бргу ќе биде освоен. Вкупните активни атински сили сега изнесувале седумдесет триери и три илјади хоплити, не сметајќи ги сојузниците на теренот. Станувало збор за забележителна воена сила, способна да притисне на Пиерија, но и на целата централна рамнина; престолнината се наоѓала на само неколку часа забрзан строев чекор. Лесно можело да се случи востаниците од Халкидик да останат без својот сојузник уште пред да добијат каква и да е помош од него; во таков случај, оваа атинска сила можела да се справи и со Потидаја.

Но, пресметките го немале предвид можното замешување од Пелопонез. Убедени дека сѐ уште ги контролираат случувањата, опсадувајќи ја Пидна и групирајќки ги своите сили, Атињаните ѝ дале драгоцено време на Потидаја. Кон крајот на мај 432, ${ }^{38}$ на четириесеттиот ден од бунтот, во Потидаја стасал Аристај Адејмантов со засилувања од Коринт. Коринтјаните сѐ уште не сакале да го прекршат Триесетгодишниот мир, па Аристај не предводел официјална коринтска војска, туку приватно собрани одреди од Коринтјани и пелопонески наемници. Но, без оглед како биле собрани, сепак, станувало збор за 1.600 хоплити и 400 лесни пешаци. ${ }^{39}$

Присуството на двеилјадна пелопонеска војска веќе значело неволја, и тоа не само во Потидаја, туку и во целиот Тракиски форосен округ. Бунтот морал итно да се пресече. Калија ги запрел дејствата против Пидна, но, без некакво при-

${ }^{36}$ Contra COLE (1974), 62, кој претпоставува дека Архестрат воопшто не бил пратен против Македонија, туку само против Потидаја, та оттаму, тврди дека Тукидид погрешно ја протолкувал неговата мисија. Сепак, против ваквата претпоставка говори усогласеноста на заедничките дејства со Филип и Дерда, кои очигледно биле веќе договорени.

${ }^{37}$ Thuc. 1.61 .

38 Thuc. 1.60.3; $c f$. GOMME 1.425.

${ }^{39}$ Thuc. 1.60 . 
мирје, не можел да биде сигурен дека Пердика нема да удри од зад грб. Примирјето, објаснува Тукидид, ${ }^{40}$ било склучено од едноставна нужда, и тоа обострана: Пердика не можел да го брани крајбрежјето додека Филип и Дерда дејствувале во срцето на кралството, а Атињаните морале неизоставно да ги фрлат сите сили против Халкидик. Пердика и Калија не склучиле мировен договор, туку привремена спогодба: нејзината важност била миговна и немала долгорочни импликации, ${ }^{41}$ но Атињаните сега можеле да минат низ Ботиаја и да влезат на Халкидик по копнен пат. ${ }^{42}$

Така завршува приказната за Филип од Амфакситида, синот на Александар I и братот на Пердика II - човекот кој, наспроти сѐ што му припишуваат современите истражувачи, веројатно воопшто и не сакал да стане крал на Македонија. По дваесетина години опстојување во Амфакситида, Филип станал жртва на политичките интереси на Атињаните, кои од практични причини ја смениле страната, го погазиле договорот со него и со Дерда, и му дале поддршка на Пердика II. Подоцнежните настани ќе покажат дека Филип сѐ уште не бил сосема отстранет од политичката сцена, но, барем за извесно време, морал да се притаи и да се откаже од амбициите за самостојност - со што завршила и неговата улога на активен чинител во внатрешната политика на македонското кралство.

\footnotetext{
${ }^{40}$ Thuc. 1.61.3.

${ }^{41}$ Треба да се споменат мислењата на KAGAN (1994), 283 ("It was an act of expediency and суnicism on both sides...") и на BORZA (1990), 143 ("Rarely can one find a clearer example of a settlement made in bad faith...").

42 Мошне интересна емендација на Тукидид и разработка кај BADIAN (1993), 175-179. Атињаните сакале да го изненадат Пердика со напад врз Бероја; токму затоа не ја префрлиле војската со триерите, кои - сосем нелогично - до Потидаја пловеле празни. Ако е точно ова, Атина треба да се обвини за уште едно прекршување на договор со Пердика, но и најпосле да се прифати дека корабите со лаги, за кои зборува Хермип, поскоро доаѓале од југ, а не од север.
} 


\section{Литература}

Anson, E. M. (1985). "Macedonia's Alleged Constitutionalism." The Classical Journal 80 (4), 303-316.

BADIAN, E. (1993). "Thucydides and the Arche of Philip". In From Plataea to Potidaea, Studies in the History and Historiography of the Pentecontaetia. Baltimore and London: JHU Press, 171-185.

BORZA, E. N. (1992). In the shadow of Olympus: the emergence of Macedon. Princeton University Press.

BorZA, E. N. (1999). Before Alexander: Constructing Early Macedonia. Publications of the Association of Ancient Historians, 6.

CARLIER, P. (1992). "Observations sur les nothoi." In R. Lonis (éd.), L'étranger dans le monde grec: actes du deuxième colloque sur l'étranger, Nancy, 19-21.

Cole, J. W. (1974). "Perdiccas and Athens." Phoenix 28 (1), 55-72.

DAHMEN, K. (2010). "The Numismatic Evidence". In Roisman, J., \& Worthington, I. (eds.). A Companion to Ancient Macedonia. Wiley-Blackwell, John Wiley \& Sons, 41-62.

ERrington, R. M. (1990). A history of Macedonia. University of California Press.

GOMME, A. W. (1981). A historical commentary on Thucydides. Oxford University Press, USA.

GRANIER, F. (1931). Die makedonische Heeresversammlung. Beck.

HAMMOND, N. G., \& GRIFFITH, G. T. (1979). A History of Macedonia II. Oxford.

HAMMOND, N. G. L. (1989). The Macedonian State: origins, institutions, and history. Oxford University Press, USA.

HATZOPOUlos, M. B. (1986). "Succession and regency in classical Macedonia". Ancient Macedonia 4. Thessaloniki, Institute for Balkan Studies, 279-292.

Hatzopoulos, M. (1996). Macedonian Institutions under the Kings: I - A Historical and Epigraphic Study; II - Epigraphic Appendix. Diffusion de Boccard.

Hodlofski, L. C. (1979). Macedonian Relations with Athens to 413 B.C., Thesis. The Pennsilvania State University.

HOFFMAN, R. J. (1975). "Perdikkas and the Outbreak of the Peloponnesian War." Greek, Roman and Byzantine Studies 16 (4), 359.

KAGAN, D. (1994). The outbreak of the Peloponnesian War. Ithaca / London: Cornell University Press.

Price, M. (1974). Coins of the Macedonians. Trustees of the British Museum.

ПроевА, Н. (1997). Студии за античките Македонци. Скопје, Macedonia Prima.

RoISMAN, J. (2010). "Classical Macedonia to Perdiccas III". In Roisman, J., \& Worthington, I. (eds.). A Companion to Ancient Macedonia. Wiley-Blackwell, John Wiley \& Sons, $145-165$. 
Westermark, U. (1989). "Remarks on the Regal Macedonian Coinage ca. 413-359 BC." In Le Rider, G., \& Hoc, S. D. N. M. (eds.). Kraay-Morkholm essays: $n u$ mismatic studies in memory of CM Kraay and O. Morkholm. Université Catholique de Louvain, Institut Supérieur d'Archéologie et d'Histoire de l'Art. 


\section{Vojislav SARAKINSKI}

\section{PHILIP, WHO WOULD (NOT) BE KING}

\section{Summary}

Philip of Amphaxitis, the brother of Perdiccas II, is usually said to be a pretender to the Macedonian throne. This alleged pretender, however, made absolutely no move against his brother until $432 \mathrm{BC}$, when Athens finally entered the fray. What is more, Philip neither struck coin, nor made an attempt to establish a legislative body or a state council of any sort. This, in addition to several other peculiarities of his arkhe in Amphaxitis, hints that he neither claimed the throne of the kingdom of the Argeadae, nor could he count on any level of support by the legislative bodies in Aegae. A thhorough analysis of the events suggests that he simply chose to act independently and stop responding to the capital. Philip moved for the throne only after losing Amphaxitis and after securing the help and support of Derdas of Elymea and Athens: before that, he had neither power, nor a strong enough motive to fight for the royal regalia. After more than twenty years of independent rule in Amphaxitis, Philip was made a victim of Athenian political interests. In 432 BC, Athens succumbed to the needs of their Realpolitik, switched sides and gave nominal support to Perdiccas II.

Keywords: PERDICCAS II, PHILIP, AMPHAXITIS, ATHENS. 